\section{Catalytic Carbon-Carbon Bond Formation from Methylene Chloride over Evaporated Titanium Films}

DURING a study of the reactions of alkyl chlorides at the surfaces of evaporated metal films we observed that a gas phase mixture of methylene chloride and hydrogen reacted in the temperature range $200^{\circ}-300^{\circ} \mathrm{C}$ at the surface of evaporated titanium to yield a variety of hydrocarbon products from $\mathrm{C}_{1}$ to a waxy polymer. Out of every hundred carbon atoms entering the reaction, not less than eighty entered products of $\mathrm{C}_{2}$ or higher. We wish to direct attention to this reaction because a polymerization starting from a $\mathrm{C}_{1}$ parent is unusual.

The reactions were carried out in a static system with initial methylene chloride and hydrogen pressures (measured at $0^{\circ} \mathrm{C}$ ) of 6.0 and 60 torr, respectively. The apparatus and technique used were similar to thoso previously used for reactions over metal films (ref. 1 and unpublished results). Gas phase analysis was by means of mass spectrometry and vapour phase chromatography. Titanium films were in the range $5-10 \mathrm{mg}$, and the effective surface area under reaction conditions was estimated by the Brunauer-Emmett-Teller method to be about $500 \mathrm{~cm}^{2}$. The reaction volume was $180 \mathrm{ml}$., and a standard reaction mixture contained $3.84 \times 10^{19}$ molecules of methylene chloride.

The composition of the products in typical reaction conditions is given in Table 1. Usually, the reaction products fell into two categories: first, gas phase hydroearbon products in the range $\mathrm{C}_{1}-\mathrm{C}_{5}$ were observed by analysis of the gase phase; and second, a colourless filmlike material which was presumably highly polymeric was recovered from the surface of the titanium after the reaction by treatment of the metal with dilute hydrofluoric acid. The material recovered in this way was found to be amorphous when examined with transmission electron diffraction in an electron microscope. The nature of the experiment did not allow sufficient material to be produced for more detailed study. Examination of the titanium itself after the reaction by transmission electron diffraction gave a pattern that indexed as ' $\mathrm{TiH}_{1 \cdot 0}$, using evaporated gold as a calibrating standard. Table 1 shows that the total number of carbon atoms which enter the polymer is in approximate agreement with the estimated weight of polymer. For example, if the polymer is assumed to be free of chlorine and of approximate composition $\left(\mathrm{CH}_{2}\right)_{n}, 330 \times 10^{-7}$ moles of incorporated carbon corresponds to a polymer weight of about $0.5 \mathrm{mg}$. Not all the polymer could be recovered, but the total amount was estimated to be of the order of $1 \mathrm{mg}$.

The extensive range of products suggests that the mechanism of this reaction may well be a complex one. A detailed account will be published of the results of an investigation into the reaction mechanism. For the present purpose, however, we may summarize the following relevant observations. (a) Ethylene and propylene were formed with about the same activation energy $(\sim 6$ kcal mole $\left.{ }^{-1}\right)$, and methane and the small amounts of ethane and propane were also all formed with about the same activation energy $\left(\sim 11 \mathrm{kcal} \mathrm{mole}^{-1}\right)$. (b) In a similar reaction with deuterium in the place of hydrogen, most of the ethylene was produced as $\mathrm{C}_{2} \mathrm{H}_{4}$. (c) Reactions at very low gas pressures (in the mtorr region) showed that surface hydrogen was not required for the process of hydrocarbon desorption, and the surface stoichiometry suggested that $\mathrm{CH}_{2}$ residues together with some more extensively dehydrogenated species were present on the surface. From these observations we tentatively suggest that the chief reaction path can be described by the following types of reactions. The notation is used where $\left(\mathrm{CH}_{2}\right)_{8}$ means a methylene group chemisorbed at the titanium surface.

$$
\begin{aligned}
& \mathrm{CH}_{2} \mathrm{Cl}_{2} \rightarrow\left(\mathrm{CH}_{2}\right)_{s}+2(\mathrm{Cl})_{s} \\
& \left(\mathrm{CH}_{2}\right)_{s}+\mathrm{CH}_{2} \mathrm{Cl}_{2} \rightarrow\left[\begin{array}{l}
\mathrm{CH}_{2} . \\
1 \\
\text { surface. }
\end{array}+\mathrm{CH}_{2} \mathrm{Cl}_{2}\right] \rightarrow \\
& \left(\mathrm{CH}_{3} \mathrm{CH}\right)_{s}+2(\mathrm{Cl})_{s} \\
& \left(\mathrm{CH}_{3} \mathrm{CH}\right)_{s} \rightarrow \mathrm{C}_{2} \mathrm{H}_{4} \\
& (\mathrm{Cl})_{s} \stackrel{\mathrm{H}_{2}}{\longrightarrow} \mathrm{HCl}
\end{aligned}
$$

The residue $\left(\mathrm{CH}_{3} \mathrm{CH}\right)_{8}$ may react further with $\mathrm{CH}_{2} \mathrm{Cl}_{2}$ to give a $\mathrm{C}_{3}$ residue. On this basis, the general propagation step is

$$
\left(\mathrm{CH}_{3}\left(\mathrm{CH}_{2}\right)_{n} \mathrm{CH}\right)_{s}+\mathrm{CH}_{2} \mathrm{Cl}_{2} \rightarrow\left(\mathrm{CH}_{3}\left(\mathrm{CH}_{2}\right)_{n+1} \mathrm{CH}\right)_{s}+2(\mathrm{Cl})_{s}
$$

The entities written within square brackets in reaction (2) are meant to indicate that a quasi free radical may be involved in the addition step, although this may only occur as the transition state is approached. We suggest that the saturates are formed by inter-residuo hydrogen transfer reactions.

Department of Chemistry,

J. R. Anderson*

B. H. MCCONKEY $\dagger$

University cf Melbourne.

Received September 26, 1967.

* Present address: School of Physical Sciences, lilinders University of South Australia, South Australia.

+ Present address: Central Research Laboratory, Imperial Chemical Industries of Australia and N.Z. Ltd., Ascot Vale, Melbourne, Vietoria. ${ }^{1}$ Anderson, J. R., and Avery, N. R., J. Catal., 5, 446 (1966),

\section{Binuclear Carbonato-complex of Chromium (II)}

WITH few exceptions, chromium (II) complexes can be simply classified according to their colours and magnetic moments. Most are blue or purple with magnetic moments which correspond to four unpaired electrons for each metal ion, but some salts of carboxylic acids are red or brown in colour and diamagnetic. Chromous acetate has beon shown to possess a dinuclear structure with a short metalmetal bond ${ }^{x}$. One species which seems to fall outside this classification is the product of the interaction of chromium (II) and carbonate ion. The simple colourless carbonate is soluble in excess aqueous carbonate media to give yellow solutions, from which yellow-brown complexes can be crystallized, such as $\mathrm{Na}_{2} \mathrm{Cr}\left(\mathrm{CO}_{3}\right)_{2} \cdot 10 \mathrm{H}_{2} \mathrm{O}$, $\mathrm{Na}_{2} \mathrm{Cr}\left(\mathrm{CO}_{3}\right)_{2} \cdot \mathrm{H}_{2} \mathrm{O}, \mathrm{K}_{2} \mathrm{Cr}\left(\mathrm{CO}_{2}\right)_{2} \cdot 3 \mathrm{H}_{2} \mathrm{O},\left(\mathrm{NH}_{4}\right)_{2} \mathrm{Cr}\left(\mathrm{CO}_{3}\right)_{2} \cdot \mathrm{H}_{2} \mathrm{O}$ (ref. 2). We have examined the yellow complex in aqueous solution by a spectrophotometric method and have shown that it contains two atoms of chromium per complex ion.

\begin{tabular}{|c|c|c|c|c|c|c|c|c|c|c|c|}
\hline Product & $\mathrm{CH}_{4}$ & $\mathrm{CH}_{3} \mathrm{Cl}$ & $\underset{C_{1}}{\text { Total }}$ & $\mathrm{C}_{2} \mathrm{H}_{4}$ & $\mathrm{C}_{2} \mathrm{H}_{6}$ & $\underset{\mathrm{C}_{2}}{\text { Total }}$ & $\mathrm{C}_{3} \mathrm{H}_{8}$ & $\mathrm{C}_{3} \mathrm{H}_{8}$ & $\underset{\mathbf{C}_{\mathbf{s}}}{\text { Totul }}$ & $\begin{array}{l}\text { Total } \\
\mathrm{C}_{4}-\mathrm{C}_{5}\end{array}$ & $\begin{array}{l}\text { Polymer (by) } \\
\text { mass balance }\end{array}$ \\
\hline $\begin{array}{l}\text { arbon appearing in indicated } \\
\text { product }\left(\text { mole } \times 1^{7}\right)\end{array}$ & 60 & 11 & 71 & 55 & 19 & 74 & 22 & 8 & 30 & Approx. 10 & Approx. 330 \\
\hline
\end{tabular}

The visible spectra of chromous acetate and of the carbonate complex are shown in Fig. l. By choosing the correct ratio of concentrations of acetato to bicarbonate, it is possible to prepare solutions with intermediate

Table 1. TYPICAI DISTRIBUTION OF PRODUCTS FROM THE REACTION OF METHYLENE CHLORIDE ON EVAYORATEII TITANIUM AT $275^{\circ} \mathrm{C}$

Total $\mathrm{CH}_{2} \mathrm{Cl}_{3}$ reacted $=516 \times 10^{-7}$ mole. 